Шевченко Марианна Юрьевна (Москва). Кандидат архитектуры. Профессор кафедры «История архитектуры и градостроительства» ФГБОУ В0 «Московский архитектурный институт (государственная академия)» (07031, Москва, улица Рождественка, дом 11/4, корпус1, стр.4. МАРХИ).Эл.почта: china-arch@yandex.ru.

Shevchenko Marianna Y. (Moscow). Candidate of Architecture. Professor of the Department of History of Architecture and Town Planning of Moscow Institute of Architecture, Moscow, Russia. E-mail: china-arch@yandex.ru.

๑ Шевченко М.Ю., 2021. Academia. Архитектура и строительство, № 4, стр. 39-48.

\title{
Феномен подобия структуры в традиционной архитектуре Китая
}

\author{
М.Ю.Шевченко, МАРХИ, Москва
}

Китайскую традиционную архитектуру отличает регулярность пространственного построения, которая прослеживается с времен позднего неолита вплоть до падения последней императорской династии в начале XX века. При сопоставлении пространственных композиций становится очевидным, что они подчинялись ряду закономерностей, а описания в текстах о ритуалах дают объяснение причинам их возникновения. В то же время всё многообразие пространственных структур оказывается возможным свести к двум базовым планировочным композициям: замкнутому двору сыхэюань и девятиклеточному квадрату. Обе данные композиции уходят корнями к древнейшим мировоззренческим представлениям об устройстве вселенной, таким как принципы инь и ян и пять элементов у-син, что обеспечило их постоянное воспроизведение в китайской традиционной архитектуре. Обозначенные планировочные композиции, проявляясь на разном масштабе, в постройках с различной функцией, привели к возникновению в китайской архитектуре такого явления как «подобие структуры».

Феномен «подобия структуры», несмотря на свою достаточно отчетливую выраженность в планировочной организации объектов различного масштаба и функционального назначения, изучен достаточно слабо. Существующие исследования планировочных или пространственных композиций в большинстве своём концентрируются на определённом типе пространственного устройства архитектурных комплексов. В данной статье исследуются процессы зарождения и эволюции феномена «подобия структуры», обосновывается его устойчивость в китайской архитектуре различных эпох, вскрывается его тесная связь с мировоззрением. Все это позволяет осветить один из аспектов преемственного характера развития традиционного зодчества Китая.

Ключевые слова: архитектура Китая, подобие структуры, планировочная композиция, пространственная регулярность.

\section{The Phenomenon of Semblance of Structure in Traditional Chinese Architecture}

M.Y.Shevchenko, MARKHI, Moscow

Traditional Chinese architecture is distinguished by the regularity of spatial layout, which can be traced from the late Neolithic times until the fall of the last imperial dynasty at the beginning of the 20th century. When comparing spatial compositions, it becomes obvious that they obeyed a number of regularities, and descriptions in texts about rituals provide an explanation of the reasons for their occurrence. At the same time, it turns out to be possible to reduce the entire variety of spatial structures to two basic planning compositions: the closed courtyard siheyuan and the nine-square field. The indicated planning compositions, appearing on a different scale, in buildings with different functions, led to the emergence in Chinese architecture of such a phenomenon as a "semblance of structure".

The phenomenon of "semblance of structure", despite its distinct manifestation in the planning organization, has been studied rather poorly. This article examines the processes of origin and evolution of the phenomenon of "semblance of structure", substantiates its stability in the Chinese architecture of different eras, reveals its close connection with the worldview. All this allows us to highlight one of the aspects of the successive nature of the development of traditional architecture in China.

Keywords: architecture of China, semblance of structure, planning composition, spatial regularity.

Исследованию особенностей планировочных композиций в китайской традиционной архитектуре посвящено достаточно много работ. Изучению закономерностей пространственных построений посвящены работы Фу Синяня и Ван Наня, древнейшие регулярные комплексы исследованы в работах Ду Цзиньпэна, Лю Сюйцзе и Ян Хунсюня, сопоставление средневековых планировок различных комплексов было проведено в трудах Фу Синяня, Хэ Цунжун, Го Дайхэн, 
Пань Гуси, Ван Шижэня и других, построение архитектурных комплексов более позднего времени (XIV - начало XX века) исследовано в работах Лю Чана, Цзя Цзюня и Сунь Дачжана. Вопросу преемственности девятичастной композиции в китайской архитектуре раннего периода посвящены работы Ван Шижэня. Формирование композиции буддийских монастырей Китая раскрыто в работах Ван Гуйсяна, жилища-сыхэюань исследованы в книгах Цзя Цзюня, Сунь Дачжана и Ма Бинцзяня, композиция погребальных ансамблей рассмотрена в работах Ван Цихэна и Пань Гуси.

Тем не менее вопросу подобия структуры архитектурных композиций различных масштаба, функций, географического положения и времени строительства достаточного внимания не уделяется. Исключением можно назвать книгу Ван Наня «Закон круга и квадрата - гармония неба и земли ${ }^{1}$, но там рассмотрен феномен единства числовых и геометрических пропорций, выражавшийся в постройках различного масштаба и функции, что раскрывает лишь один аспект подобия структуры в китайской архитектуре.

Слабая зависимость структуры архитектурных комплексов от функционального назначения, опора практически всех планировок на композицию сыхэюань или девятиклеточного квадрата, в китайских исследованиях воспринимается как данность, и на этой особенности обычно не заостряется внимание. В то же время эта устойчивая планировочная организация привела к такой важнейшей эволюционной характеристике китайского зодчества, как многовековая преемственность развития. В связи с этим хотелось бы отдельно изучить причины формирования устойчивых планировочных композиций, определить время возникновения базовых планировочных структур, что позволило бы лучше понять закономерности развития китайской традиционной архитектуры.

\section{Композиция сыхэюань}

Археологические находки построек позднего неолита уже демонстрируют наличие в их планировочной структуре определённых закономерностей, которые впоследствии прочно вошли в китайскую традиционную архитектуру [1, c. 150]. Так, дворцовые комплексы, обнаруженные в районе Эрлитоу провинции Шэньси и датирующиеся XVIII веком до н.э., выстроены в соответствии с композицией сыхэюань, то есть представляют собой прямоугольные дворы, окружённые стенами и постройками с четырёх сторон, ориентированные в сторону юга с подчёркнутой центральной осью (рис. 1 Б). Крупные постройки того периода также имели прямоугольные планы, симметричную структуру, были ориентированы в сторону юга, а центральное пространство в них, судя по текстам, стало обретать особое значение с точки зрения проведения церемониальных действий ${ }^{2}$ (рис. 1 А). Обнаруженные позднее остатки города Шанчэн в районе Яньши провинции Шаньси, который датируется XVI веком до н.э., демонстрируют, что и в масштабе города прослеживаются схожие планировочные моменты [2, с. 381]. Построенный сразу после возведения дворца малый город имеет прямоугольные очертания, по периметру окружён стеной, дворец расположен на оси, в центральной части города. И дворец, и сам город ориентированы на юг (рис. 1 В).

Если обобщить рассмотренные планировочные особенности, то можно выделить простейшую схему, которая и легла в основу структуры как отдельных зданий, так и архитектурных комплексов и городов периода неолита. В основе планировочной организации лежит прямоугольник, ориентированный по сторонам света, обращённый главным входом в сторону юга, композиция его симметрична, а ось симметрии проходит через южный вход. Центр композиции выделяется либо главным помещением, либо главной постройкой, либо главным

${ }^{1}$ 王南 (Ван Нань). 规矩方圆——天地之和 (Закон круга и квадрата - гармония неба и земли) : В 2 т. - Пекин : Чжунго цзяньчжу гунъе, 2019.

${ }^{2}$ [周]《仪礼》(Правила этикета И-ли, дин. Чжоу). (https://ctext.org/yili/xiang-yin-jiu-li).
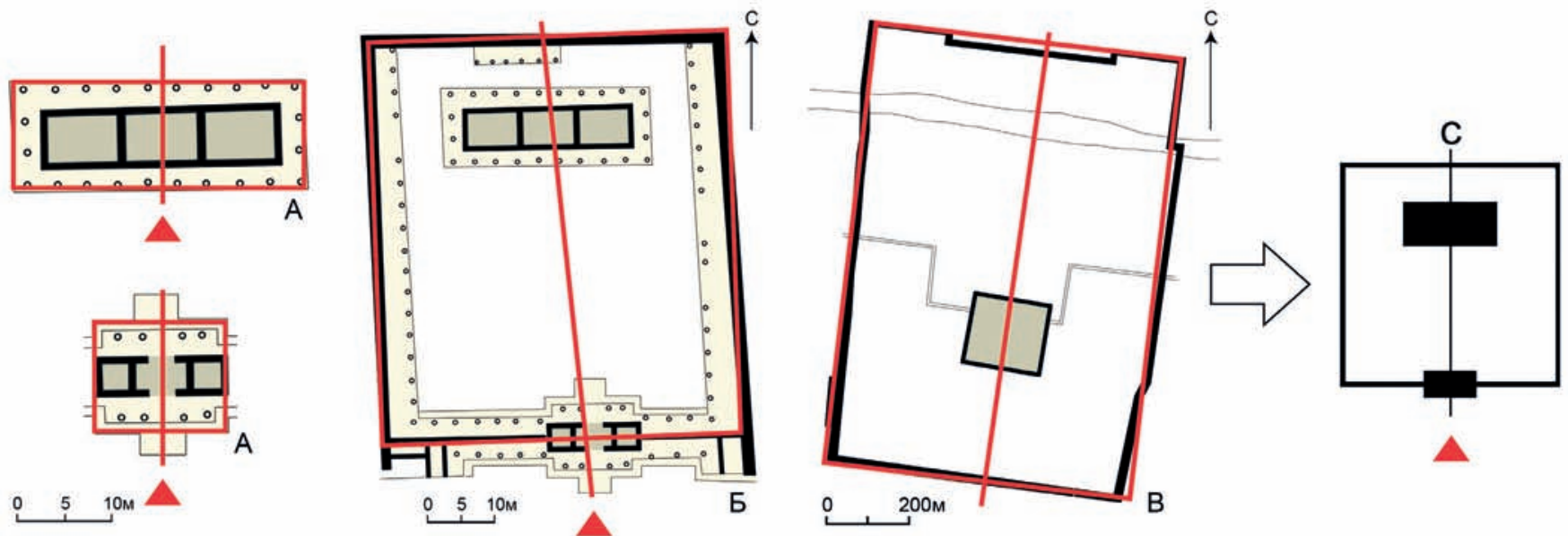

Рис. 1. Зарождение принципа подобия структуры в неолитических постройках: $A$ - постройки комплекса № 2 в Эрлитоу, провинция Шэньси; Б - план комплекса № 2 в Эрлитоу; $B$ - план малого города Шанчэн в Яньши, провинция Шэньси. Автор схемы М.Ю. Шевченко 
комплексом, к примеру, дворцом. Центральный объект также располагается на композиционной оси, соосно южному входу. Нередко центральные объекты сдвигались ближе к северу для высвобождения пространства двора, которое требовалось для осуществления определённых ритуалов.

Как видно на рисунке 1, в ранних постройках лишь начинается следование обозначенной регулярной композиции, поэтому в их построении заметны некоторые несовершенства: симметрия не всегда соблюдена, композиционная ось может быть недостаточно акцентирована, расположение ворот и главных входов также могло варьироваться и не всегда городские и дворцовые ворота располагались на единой оси, также и ориентация по сторонам света могла иметь некоторые отклонения от оси север-юг. Тем не менее именно неолитический период можно считать временем зарождения композиции сыхэюань, вытекающей из неё простейшей пространственной схемы, а значит и принципа подобия структуры в китайской традиционной архитектуре.

В более поздней архитектуре данная тенденция продолжит своё развитие. Находки архитектурных комплексов династии Чжоу демонстрируют дальнейшее развитие композиции сыхэюань. Группа сооружений в районе Фэнчу провинции Шэньси [1, с. 276-277], построенных при Западном Чжоу (XI век до н.э.), представляет собой полноценный архитектурный комплекс, сооружённый в соответствии с правилами композиции сыхэюань (рис. 2 Б). В более поздних постройках династии Чжоу данная композиция получит воплощение не только во дворцовых (комплекс № 3 в районе Мацзячжуан [1, c. 236]), но и храмовых (Юньтан, Цичжэн [3, с. 6], комплекс № 1 в Мацзячжуан [1, с. 264], Хоума [4]), и погребальных (захоронение правителя царства Чжуншаньго [5], захоронение в районе Хуэйсянь [6] провинции Хэнань). То есть уже при династии Чжоу комплексы с различными функциями начинают приобретать схожую планировочную структуру.
Что касается отдельных построек, то и здесь продолжаются тенденции, заложенные ещё в эпоху неолита. Главные постройки комплексов устанавливаются на их центральной оси, имеют прямоугольные или близкие к квадрату очертания. Каркасная система требовала упорядоченного размещения несущих опор, которыми в центральной части построек выделялось особое пространство, служившее для проведения необходимых церемоний. 0 важности такого пространства между двумя центральными столбами ин(楹) можно узнать

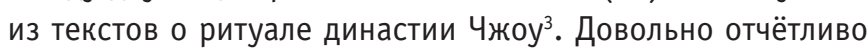
такая структура выражена, к примеру, в постройках комплекса № 1 в Мацзячжуан, датируемого VI веком до н.э. (рис. 2 A).

Археологические данные о городах Чжоу показывают, что уже при Западном Чжоу (XI-VIII века до н.э.) формируется определённый размер города правителя, который составлял около 12-16 кв. км [1, с. 226-255]. Города обретают близкую к прямоугольной форму, обносятся стенами из утрамбованной земли, как правило, выдерживается ориентация городов по сторонам света, главные ворота обычно помещают на юге, а дворцовые сооружения - в центре (рис. 2 В). Археологами был обнаружен ряд меньших городов времён правления Восточного Чжоу (VIII-III века до н.э.) площадью 1-3 кв. км, которые также демонстрировали все вышеперечисленные особенности.

При династии Чжоу происходит также развитие планировочных композиций и формирование ряда пространственных стереотипов, нашедших свое воплощение в дворцовом зодчестве всех последующих эпох. Часть из них была тесно связана с композицией сыхэюань. Речь идёт о стереотипах трёх парадных залов, пяти ворот и шести дворцов (в женской части дворцового города) у правителя. Одним из первых находит свое воплощение стереотип трёх парадных залов. Три парадных зала, или саньчао (三朝), впервые упоминаются в трактате Чжоули (по разным версиям, датировка Чжоули варьируется от XI до III веков до н.э. [7]). Данные археологии доносят до нас свидетельства на-

3 В «И-ли» сказано: «[Гость и хозяин] приветствуют друг друга, принимая кубок от хозяина между столбами ин». Правила этикета И-ли, дин. Чжоу 介揖让升，授主人爵于两楹之闲). [周]《仪礼》(https://ctext.org/yili/xiang-yin-jiu-li).
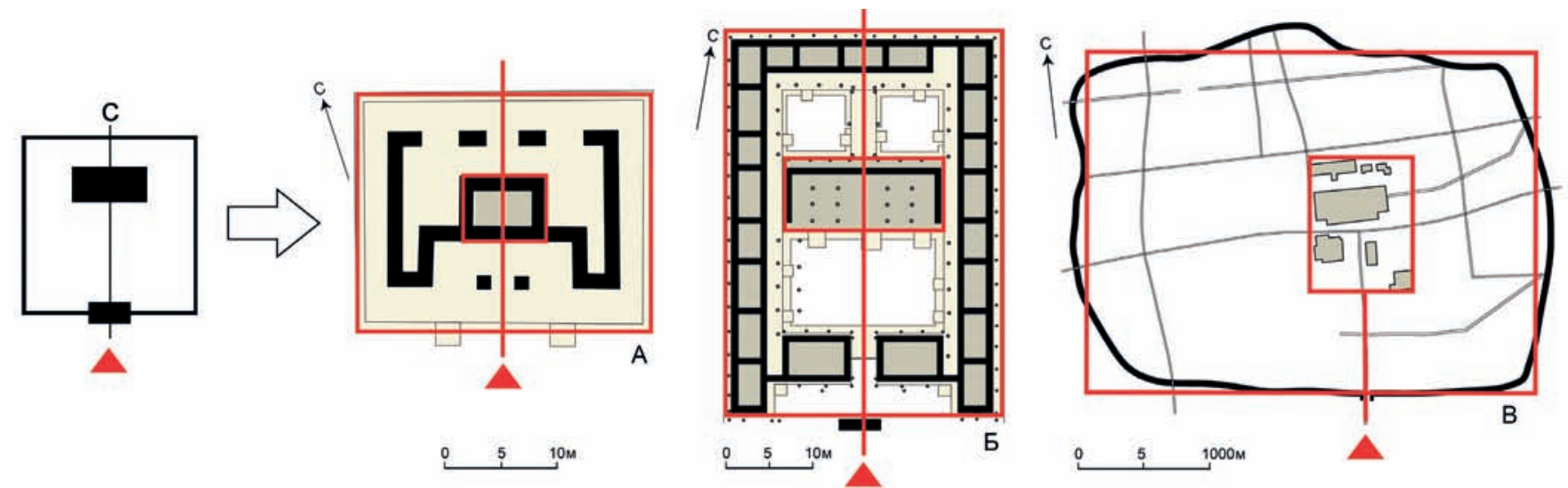

Рис. 2. Проявление подобия структуры на примере архитектурных объектов династии Чжоу: А - постройка комплекса № 1 в Мацзячжуан; Б - комплекс в Фэнчу; В - планировка столичного города Цюйфу княжества Лу. Автор схемы М.Ю. Шевченко. 
личия при династии Чжоу композиции с тремя равноценными по размерам постройками, размещёнными внутри одного двора. И самым ранним примером тому могут служить комплексы № 1 и № 3, обнаруженные в районе Мацзячжуан провинции Шэньси [1, с. 264]. Впоследствии при династиях Суй и Тан (VI-X века) парадные залы размещали в соответствии с текстом трактата - перед последними из пяти ворот устанавливалась внешняя аудиенция, а за ними - две внутренние. Однако с воцарением династии Мин (после XIV века) сложилась традиция размещения трёх парадных залов на едином многоярусном основании в одном дворе (императорские дворцы в Нанкине и Пекине).

Самое раннее из обнаруженных археологами воплощение стереотипа пяти ворот демонстрирует комплекс № 3 в районе Мацзячжуан (VI век до н.э.). Правило о возведении пяти ворот у сына Неба было также зафиксировано в трактате Чжоули 4 . Пять ворот располагались друг за другом по единой центральной оси дворца, формируя чередование пяти дворов. Данное правило позднее нашло воплощение в структуре дворцов города Ечэн царства Вэй, в городе Цзянькане периода Восточной Цзинь и Южных династий [8], в Лояне династии Северная Вэй [9], в городе Южном Ечэне династий Восточная Вэй и Северная Ци [10, с. 104-106], во дворцах Тайцзигун и Дамингун города Чанъаня династии Тан [10, с. 385, 403], в столице династии Сун - городе Бяньцзине, а также в последних столицах Китая - городе Нанкине династии Мин и городе Пекине династий Мин и Цин [11, с. 113, 118].

Ещё один пространственный стереотип, закреплённый в трактате о ритуалах Чжоули, это правило устройства шести дворцов в женской части дворца 5 . Археологами не было

4 [战国]《周礼·天官》(Чжоули, глава Тяньгуань, примечание Чжэн Сюаня: «У сына Неба пять ворот: внешние называются гаомэнь, вторые - чжимэнь, третьи - кумэнь, четвертые - инмэнь, пятые - лумэнь». 郑玄注: “王有五门外曰泉门二曰雉门三曰库门四 日应门五曰路门”). (https://ctext.org/wiki.pl?if=en\&chapter=372560).

${ }^{5}$ [战国]《周礼.天官》(Чжоули, глава Тяньгуань): «В соответствии с ритуалом инь (женским этикетом) следует [сооружать] шесть дворцов». “以陰礼呚六宫”. (URL: https://ctext.org/wiki.pl?if=en\&chapter=87309).

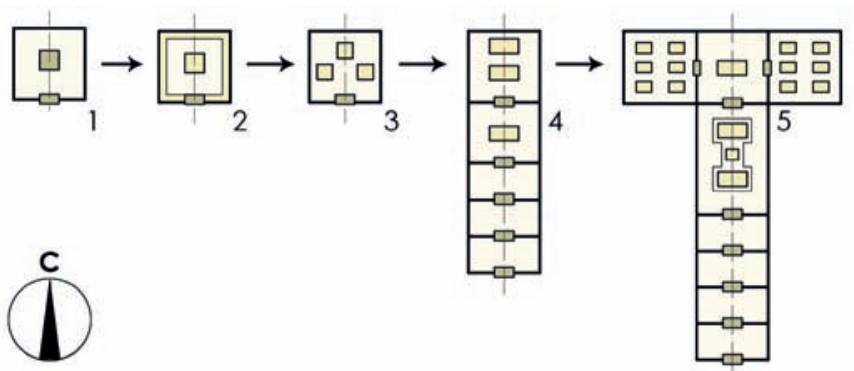

Рис. 3. Схема развития пространственных стереотипов на базе композиции сыхэюань: 1 - базовая пространственная схема; 2 - простейшая композиция сыхэюань; 3 - двор с тремя постройками; 4-стереотип трёх парадных залов и пяти ворот; 5 - совмещение стереотипов трёх парадных залов, пяти ворот и шести дворцов в одном комплексе. Автор схемы М.Ю. Шевченко обнаружено планировок жилой и внешней частей крупных дворцов правителей времён династии Чжоу, которые бы демонстрировали реализацию данного правила, однако после того, как трактат Чжоули вошёл в число книг классического конфуцианского Тринадцатиканония, он стал обязательным для изучения, и многие его положения нашли воплощение в организации дворцовой структуры, и, в частности, правило шести дворцов неоднократно воплощалось впоследствии, примерами чему могут служить дворцы Тайцзигун города Чанъаня династии Тан [10, с. 385, 403], императорские дворцы в городах Нанкине и Пекине династии Мин [11, с. 113, 118].

Структура данных пространственных стереотипов имеет определённые общие закономерности, и при визуальном сравнении планировочных схем становится очевидным, что она восходит корнями к вышеописанной базовой композиции, проявившейся еще в эпоху неолита (рис. 3).

Со временем на базе композиции сыхэюань формируются также планировки различных культовых комплексов, причём это относится не только к исконно китайским верованиям, таким как даосизм, конфуцианство, культы предков и различных божеств, но и к заимствованным религиям, таким как буддизм [12] и мусульманство [13]. Схожесть планировочной структуры потребовала возведения определённых знаковых объектов внутри комплексов, которые бы указывали на их функциональную принадлежность. Так, в конфуцианских монастырях в передней части появляется входная группа с ритуальными воротами линсинмэнь и полукруглым прудом с мостиком над ним, в буддийских монастырях за главными воротами начали устанавливать колокольную и барабанную башни, зачастую довольно скромного размера, скорее напоминающие парковые павильоны или беседки, также некоторые буддийские монастыри выделялись наличием
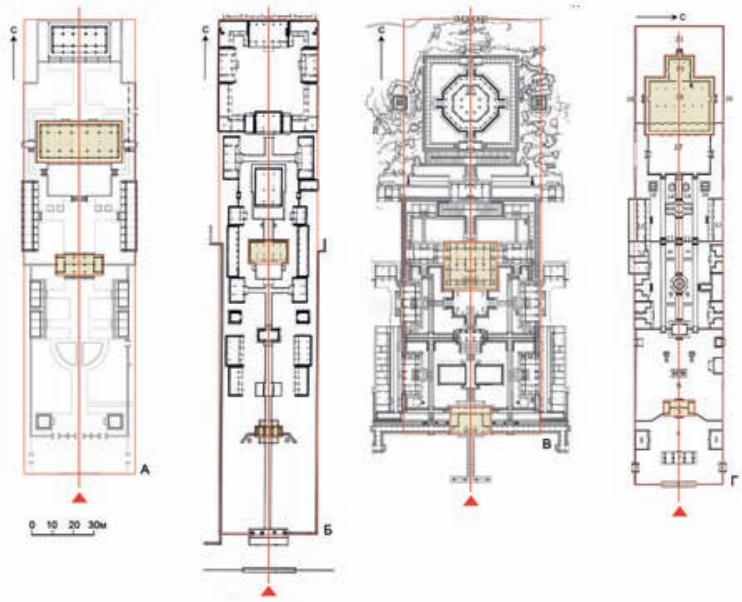

Рис. 4. Сравнение планировок культовых построек времён династий Мин и Цин (XIV-XVIII века): А - храм Конфуция в Куньмине, провинция Юньнань; 5 - даосский монастырь Байюньгуань в Пекине (центральная часть); $B$-буддийский монастырь Яньшоусы в парке Ихэюань в Пекине; Г - Великая мечеть в Сиане, провинция Шэньси. Цветом выделены главные ворота и постройки. Автор схемы М.Ю. Шевченко 
пагод - типично буддийских построек, даосские монастыри - изображениями символа инь-ян, окружённого восемью триграммами, мечети можно было распознать по очень крупным размерам молитвенных залов, по деревянным теремам-минаретам, а также по необычной ориентации не в сторону юга, а на запад - в сторону Мекки, и так далее. Именно схожесть структуры различных комплексов повлияла на то, что большое значение со временем стали приобретать доски с названием сооружений, которые навешивались на главные фасады зданий. По именованию построек и комплексов можно было сразу понять назначение того или иного архитектурного объекта. Со временем сами доски с названиями превратились в отдельный вид каллиграфического и резчицкого искусства, надписи нередко выполнялись императорами или видными государственными или религиозными деятелями, что лишь доказывает особую значимость данных элементов в китайской архитектуре, служивших своего рода ориентирами, поскольку архитектура сама по себе не могла в полной мере выявить функциональное назначение построек. Другими способами ориентации внутри архитектурной застройки городов служили также цвет, декоративная отделка, строительные материалы и т.д. - опять же средства, не связанные с архитектурной композицией, которая в силу феномена подобия структуры была довольно схожей у объектов различного назначения (рис. 4).

На рисунке 4 показано проявление феномена подобия структуры в объектах различного функционального назначения. Но и на уровне разного масштаба в архитектуре более поздних эпох подобие структуры также находило свое воплощение. Для примера нами были выбраны три отличающиеся по масштабу объекта, относящиеся к наиболее известным памятникам архитектуры различных эпох. Как отдельная постройка выбран план зала Священной праматери в храмовом комплексе Цзиньцы в городе Тайюань провинции Шаньси, датируемый династией Сун (начало XII века), как архитектурный комплекс - гробница Чанлин императора Цзяцина династии Цин (XIX век), в качестве крупного градостроительного образования - дворец Тайцзигун династии Тан (VII век). При выборе примеров помимо масштаба учитывались также различия во времени строительства и в функциональном назначении, что позволило ещё более явно показать, как принцип подобия проявлял себя не только в объектах различного масштаба и назначения, но и различных эпох (рис. 5).

\section{Композиция девятиклеточного квадрата}

При династии Чжоу происходило не только прямое развитие композиции сыхэюань, но также и её некоторое усложнение и видоизменение. В то время осмысливаются появившиеся ранее основные нумерологические представления, число «9» становится символом неба и императора, вырабатывается девятичастная структура планировки центрического храма-дворца минтана, который для чжоусцев имел огромное ритуальное значение [14].

Структура девятиклеточного квадрата была использована и при планировке древних рынков времён династий Чжоу и Хань. В «Чжоули» в разделе «Дунгуань» структура рынка описана достаточно подробно, из чего можно сделать вывод о том, что у рынков была строго упорядоченная регулярная структура [15]. Рынок располагался на квадратной в плане
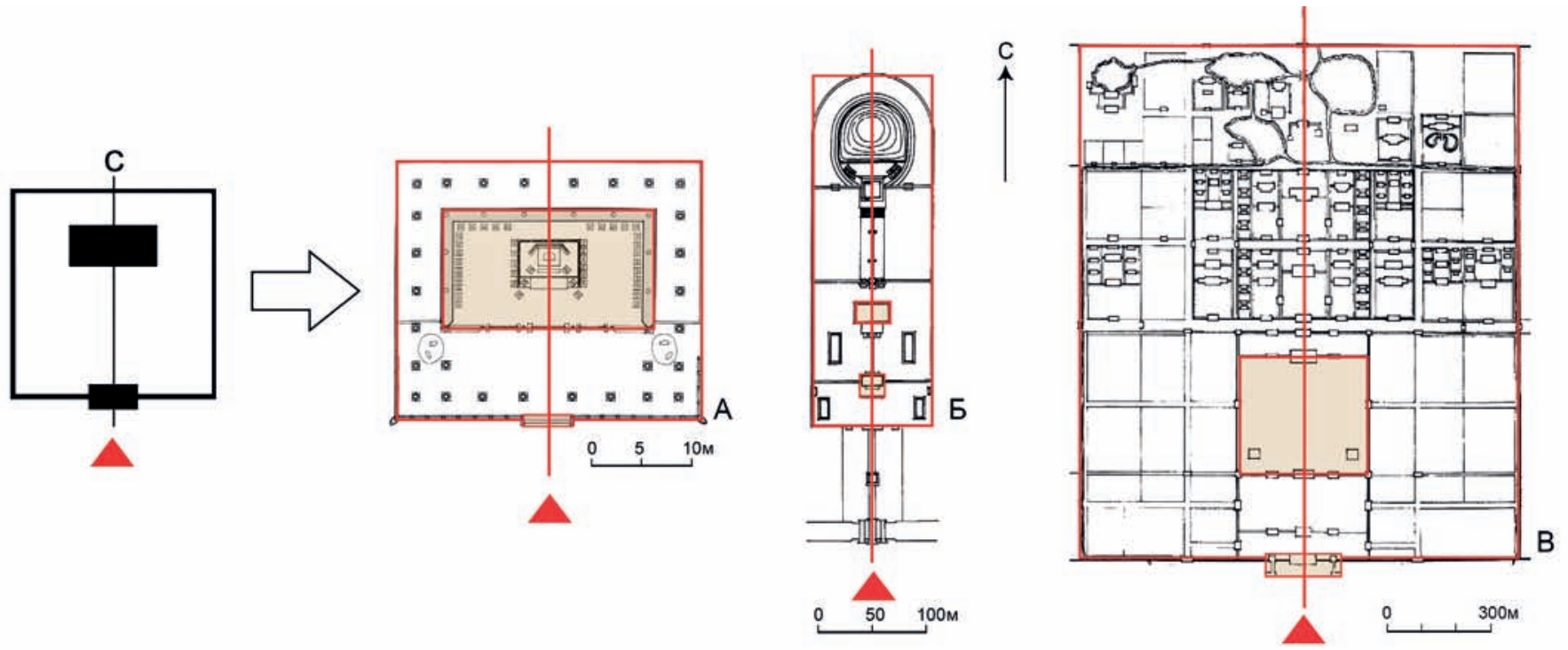

Рис. 5. Проявление единых планировочных принципов в объектах различных масштаба, функционального назначения и эпох строительства: A - храм священной праматери в комплексе Цзиньцы. Город Тайюань, провинция Шаньси (начало ХII века); Б - план захоронения Чанлин императора Цзяцина. Город Баодин, провинция Хэбэй (ХІХ век); план дворца Тайцзигун. Город чанъань, провинция Шэньси (VII век). Автор схемы М.Ю. Шевченко 
территории, которая делилась на огороженные участки, где продавались определённые виды товаров. В центре рынка была размещена башня управляющего, по сигналу которого начиналась и заканчивалась торговля на рынке ${ }^{6}$.

При династии Чжоу философ Мэн-цзы разрабатывает также концепцию «колодезных полей» (цзин-тянь), в основе которой лежал образ участка земли (поля) в виде девятиклеточного квадрата со стороной в 1 лит (рис. 6 Б).

Термин «колодезное поле» отсылает к форме иероглифа цзин - 井, который по форме напоминает поле, разделённое на девять частей. Колодезные поля принадлежали правителю и отдавались в пользование земледельцам. Восемь частей были в частном пользовании, а одна часть - в общинном [16]. Урожай с восьми частей земледельцы оставляли себе, а с одной части поля отдавали правителю в качестве налога. Разработанная концепция позволила Мэн-цзы уточнить размеры территории китайских государств, то есть регулярный девятиклеточный квадрат лёг в основу расчёта размеров территории государства. Это довольно важный момент, раскрывающий традиционное пространственное восприятие в Древнем Китае.

Представление о делении государственных земель в соответствии с концепцией колодезных полей легло в основу планировки идеального города правителя, которая впервые была записана в разделе «Каогунцзи» трактата «Чжоули». Данный раздел, название которого можно перевести как «Записки об исследовании ремёсел», был посвящён теории и практике ремесленного производства [17]. Судя по описанию в трактате, столичный город также должен был иметь девятичастную структуру с дворцом, расположенным по центру (рис. 6).

При династии Сун в трактате «Саньлиту» появились также иллюстрации к соответствующим описаниям, приведённым в трактате Каогунцзи, показывавшие структуру храма-дворца минтана и столичного города ${ }^{8}$ (рис. 7). Структура минтана там изображена очень условно, так что довольно сложно понять его внутреннее устройство, за исключением того, что в нём было девятичастное деление квадратного плана. Весь комплекс должен был окружаться стеной с воротами с каждой стороны. План столицы правителя выполнен также достаточно схематично, однако на нём совершенно чётко обозначено местоположение дворца в центральной части города. Начиная со столицы Бяньцзин династии Сун (X-XIII века) вплоть до последней столицы - города Пекина (XIV-XX века), все столичные города Китая имели планировочную структуру с дворцовым или императорским городом, установленным в центральной части городской территории.

Иными словами, структура девятиклеточного квадрата, также как и композиция сыхэюань, проявила себя в сооружениях различного функционального назначения и различного масштаба. В более поздней архитектуре она периодически будет встречаться в культовых постройках (минтан, алтарь духов Шэ и Цзи), дворцовых постройках (дворец Цзюхуагун $[10$, с. 60], возведённый в городе Ечэн при династии Поздняя Чжао), в планировке градостроительных объектов (рынки китайских городов Дасин, Чанъань, а также Хэйан-кё в Японии $[18$, с. 36-37]) планировке городов (суйский Дасин, минский Пекин), хотя ввиду большей сложности и меньшей гибкости данная композиция была менее распространена, нежели композиция сыхэюань. Однако в структуре центрических сооружений внутри храмовых, парковых и дворцовых комплексов она нашла довольно широкое применение. В то же время в структуре девятиклеточного квадрата можно проследить элементы выявленной выше базовой планировочной схемы, а именно: прямоугольность плана, окружение плана стеной, ориентация в сторону юга, симметрия.

\section{Связь базовых планировочных композиций с мировоззрением}

Анализ планировочной организации архитектурных комплексов показал, что наиболее базовыми в китайской тради-

${ }^{6}$ [战国]《周礼·地官》(Чжоули, глава Дигуань ) (https://ctext.org/wiki.pl?if=en\&chapter=831387).

${ }^{7}$ [周] 孟子 (Мэн-цзы). 滕文公上(Глава Тэн Вэньгун). Дин. Чжоу. (https://ctext.org/mengzi/teng-wen-gong-i).

${ }^{8}$ [宋] 聂崇义 《三礼图》 (Не Чунъи. Иллюстрации к трем книгам о ритуалах «Саньлиту», дин. Сун). (https://ctext.org/library.pl?if=en\&file=80315\&page=85 ; https://ctext.org/library.pl?if=en\&file=80315\&page=89).
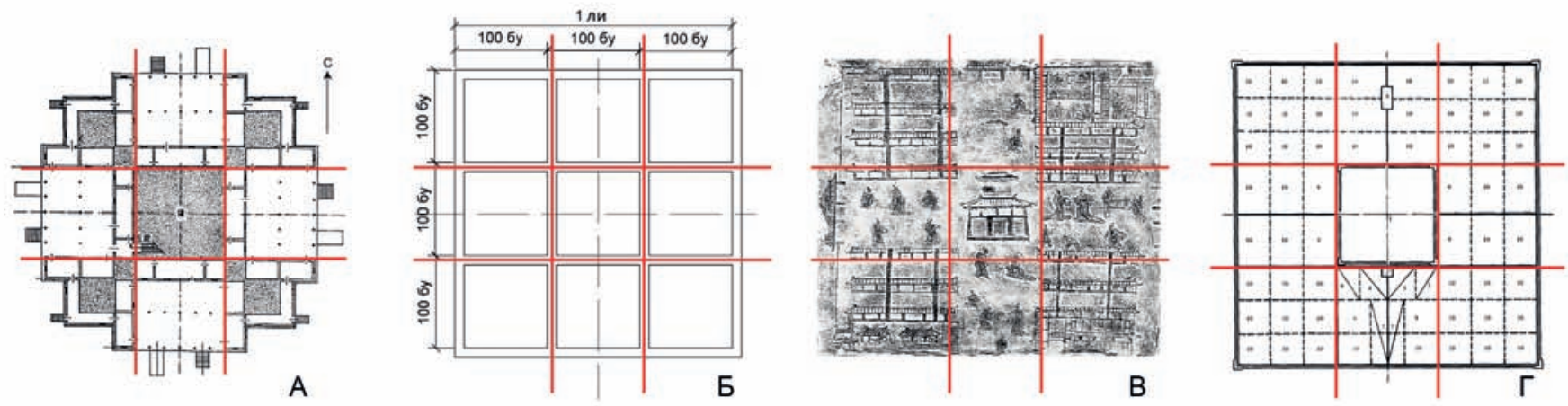

Рис. 6. Проявление подобия девятичастной структуры на примере объектов династий Чжоу и Хань: А - план храма-дворца минтана династии Чжоу; 5 - схема колодезного поля по Мэн-цзы; В - структура рынка на керамической пластине династии Хань (I-II века); Г- структура столицы правителя по Каогунцзи. Автор схемы М.Ю. Шевченко 
ционной архитектуре являются две планировочные композиции: композиция сыхэюань и композиция колодезного поля цзин-тянь. Сравнение особенностей планировок отдельных построек, архитектурных комплексов и городов выявило, что в своей основе они следовали схожим принципам. Отдельные сооружения имели прямоугольные планы и симметричную внутреннюю структуру. В основе любого архитектурного комплекса лежал прямоугольный двор, выстроенный в соответствии с композицией сыхэюань. Это приводило к тому, что все крупные планировочные объекты, включая и города, получали регулярную, строго упорядоченную композицию. Такое подобие просматривается как на уровне различного масштаба, так и на уровне различных функций построек и поселений.

Развитие шло от простейшей планировки прямоугольного двора, ориентированного по сторонам света, до сложных градостроительных объектов. Во всех объектах, независимо от их масштаба - будь то отдельные постройки или столичные города, можно выявить схожие черты построения. Это:

- прямоугольность планов,

- выделение центра,

- обнесение объекта или комплекса стеной,

- ориентация по сторонам света,
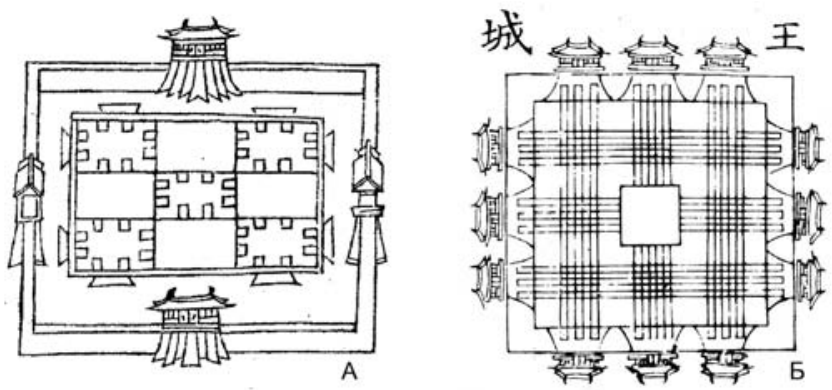

Рис. 7. План минтана (А) и столицы правителя (Б) из трактата Саньлиту (XI век)

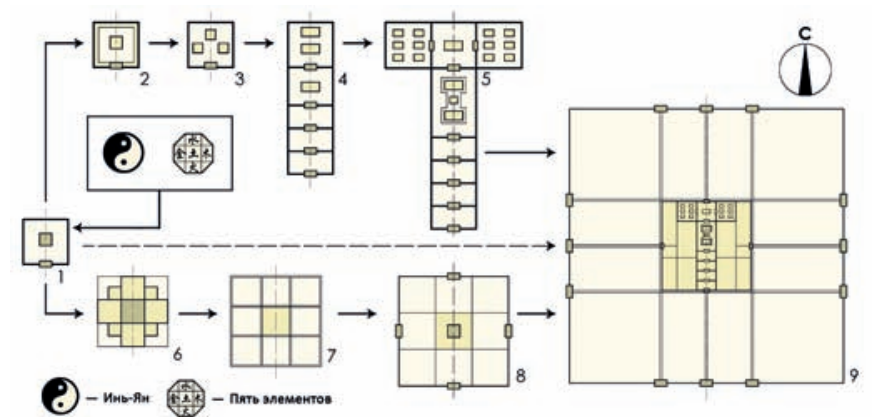

Рис. 8. Проявление принципа подобия структуры и развитие типологии регулярной планировки: 1 - базовая планировочная схема; 2-5 - развитие типологии сыхэюань; 6-8 - развитие типологии девятиклеточного квадрата; 9 - совмещение композиций сыхэюань и девятиклеточного квадрата в планировке столичного города. Автор схемы М.Ю. Шевченко
- устройство главного входа на юге,

- акцентирование центральной оси юг-север.

Обозначенные особенности формируют простейшую планировочную схему, которая отразилась как в построении отдельных зданий, так и в композиции сыхэюань, и более сложной девятичастной структуре, что говорит об их мировоззренческом родстве. Как было показано выше, правила построения архитектурных комплексов и городов во многом носили стереотипный характер и не зависели ни от функции построек, ни от масштаба строительной задачи.

Анализ традиционных мировоззренческих представлений Китая выявил наличие глубокой взаимосвязи между базовыми мировоззренческими принципами и простейшей планировочной схемой, что обусловило устойчивость данной структуры на протяжении тысячелетий. Основными мировоззренческими принципами, повлиявшими на формирование регулярной планировки, стали принципы инь и ян и пять элементов у-син. (рис. 8).

Ниже мы рассмотрим, каким образом выявленные нами закономерности регулярной планировочной организации были связаны с указанными мировоззренческими концепциями.

Прямоугольность планов построек, комплексов или городов базировалась на идее пяти элементов у-син. Так как каждому элементу соответствовала определённая сторона света и центр, то желание подчеркнуть взаимосвязь постройки с базовыми элементами мироздания приводило к созданию прямоугольной или квадратной композиции.

Выделение центра также связано с идеей пяти элементов, так как помимо обозначения четырёх сторон света необходимо было также акцентировать центр, который занимал элемент «земля». Выделение центра производилось путём размещения там главного объекта или пространства. Это просматривается и в структуре отдельных сооружений: во дворцах по центру ставился трон, в храмах - постамент со статуями, в жилищах обустраивалось место встречи гостя, в захоронениях - статуя усопшего и так далее. В храме-дворце минтане центральный зал назывался Великим залом тайши и стоял несколько особняком от остальных четырёх, располагаясь по центру сооружения. В системе колодезных полей именно центральное поле принадлежало императору, и собранный с него урожай отдавался в качестве налога. В планировке городских рынков по центру устанавливали рыночную башню, с которой осуществлялся контроль за территорией, там же можно было обменять деньги и решить другие сопутствующие вопросы. В планировке города, начиная со времён правления династии Сун, дворец также начал помещаться именно в центре города, а центром самого дворца стал тронный зал императора.

Обнесение объекта или комплекса стеной позволяло обозначить границы, выделить комплекс из окружения, ещё более подчеркнув тем самым взаимосвязь с пятью элементами. В целом ограничение территории стеной с древнейших времен имело для жителей Китая большое значение. Стеной ограждались отдельные дворы, комплексы, в которые входили отдель- 
ные дворы, городские кварталы, состоявшие из комплексов, сами города. И даже государства также огораживались по периметру стенами (отдельные стены княжеств при династии Чжоу [1, с. 323] или Великая китайская стена, строительство которой начал император Цинь Шихуан после объединения страны [19]), которые по факту не были прямоугольными в плане, но по представлениям, зафиксированным в текстах, всё же следовали общей логике пространственной организации, что и было отражено в идее Мэн-цзы о делении территории всей империи по принципу девятиклеточного колодезного поля. Концепция ограждающей стены стала в архитектуре Китая своего рода архетипическим элементом пространственного ощущения и проявляется даже в современной китайской архитектуре вплоть до наших дней [20, с. 127-140].

Ориентация по сторонам света связана как с идеей пяти элементов, так и с принципами инь и ян, поскольку они символизировали две стороны света - север и юг соответственно.

Устройство главного входа на юге связано главным образом с представлениями о принципах инь и ян. Ян символизировал не только юг, но и жизнь, поэтому с древнейших времен ориентации в сторону юга уделялось особое внимание. На юг ориентировались и основные постройки, входившие в комплексы. Хотя были отдельные сооружения, которые предписывалось ориентировать на север. Примером тому может служить алтарь Земли (как противоположности Небу). В паре «Небо-Земля» Земля выражала принцип инь, который был связан с севером. Именно поэтому такие сооружения и были обращены на север. Но здесь опять же налицо связь с парой инь-ян и её отражение в планировочной организации архитектурных комплексов. Остальные объекты традиционной архитектуры в основном ориентировались на юг. Это были дворцы, монастыри, храмы, погребальные комплексы, жилища и резиденции, школы, а также целые города - уездные и столичные.

Акцентирование центральной оси юг-север также связано с концепцией инь-ян. Человек в древнем Китае осознавал себя находящимся между небом (ян) и землёй (инь), а при переносе данной оси в горизонтальную плоскость - между югом и севером. Так что акцентирование центральной оси подчёркивало значимость принципов инь (север) и ян (юг).

\section{Выводы}

Преемственность мировоззренческих принципов, закреплённых со временем в конфуцианском учении, обеспечила их непрерывное воспроизводство в архитектуре, что также повлияло и на преемственность традиции регулярной планировки.

Появившиеся в Китае ещё во времена неолита и бронзового века, простейшие планировочные схемы прямоугольного двора и девятиклеточного квадрата продолжили применяться в китайской архитектуре вплоть до начала XX века. Они находили свое выражение в объектах различного масштаба и функционального назначения, что и привело к возникновению феномена подобия структуры.

Слабое проявление функции в пространственном построении архитектурных комплексов привело к тому, что в китайской архитектуре был выработан целый ряд вспомогательных средств, главным образом декоративных, помогавших ориентироваться в архитектурном окружении городов и поселений.

Регионы, исторически развивавшиеся без значительного конфуцианского влияния, такие как северо-западный Синьцзян или северная Внутренняя Монголия, в гораздо меньшей степени демонстрируют следование принципу регулярной планировки. Также и соседние страны, такие как Корея и Япония, - как только они выходили из конфуцианского поля влияния, сразу же отходили от строгой регулярности построения архитектурных комплексов и городов. В связи с этим можно предположить, что традиция пространственной регулярности, зародившись в Китае ещё до конфуцианства, но будучи полностью воспринятая им, стала впоследствии маркером присутствия конфуцианства в культуре региона. 


\section{Лuтература}

1. 刘叙杰。中国古代建筑史 (Лю Сюйцзе. История древней архитектуры Китая) : В 5 томах. - Т.1. - Пекин : Чжунго цзяньчжу гунъе, 2009. - 717 с.

2. 杜金鵬。夏商周考古学研究 (Ду Цзиньпэн. Археологические исследования эпох Ся, Шан и Чжоу). - Пекин : Кэсюэ, 2007. - 789 с.

3. 周原考古队。陕西扶风云塘, 齐镇西周建筑基址 1999-2000年度发掘简报 (Археологическая команда по исследованию истоков династии Чжоу. Краткий археологический отчет за 1999-2000 гг. с места раскопок сооружений в районах Юньтан и Цичжэн провинции Шэньси) // 考古 (Археология). - 2002. - № 9. - С. 3-26.

4. 山西省考古研究所侯马工作站。山西侯马晋国遗址牛 村古城的试掘 (Научно-исследовательский институт археологии провинции Шаньси, рабочая стоянка в Хоума. Раскопки древнего города Нюцунь царства Цзинь в районе села Хоума, провинции Шаньси) // 考古与文物 (Археология и культурное наследие). - 1988. - № 1. - С. 57-60.

5. 河北省文物管理处。河北省平山县战国时期中山国 墓葬发掘简报 (Отдел культурного наследия провинции Хэбэй. Краткий археологический отчёт о раскопках захоронения царства Чжуншаньго периода Чжаньго в районе Пиншань, провинции Хэбэй.) // 文物 (Культурное наследие). - 1979. - № 1. - C. 1-31.

6. 中国科学院考古研究所。辉县发掘报告 (Отдел археологии академии наук КНР. Отчёт о раскопках в Хуэйсяне). - Пекин : Кэсюэ, 1956. - 115 с.

7. Юркевич А.Г. Чжоу ли / Духовная культура Китая: энциклопедия: в 5 т. Т. 1. Философия // ред. М.Л. Титаренко, А.И. Кобзев, А.Е. Лукьянов. - М. : Восточная литература, 2006. - 727 c. - C. 583.

8. 徐光冀，顾智界。河北临漳业挑城遗址勘探发掘简 报 (Сюй Гуанцзи, Гу Чжицзе. Краткий отчёт об исследовании северного города Ечэн в районе Линьчжан провинции Хэбэй) // 考古 (Археология). - 1990. - № 7. - С. 595-600.

9. 杜玉生，肖淮雁，钱国祥。北魏洛阳外廓城和水道 的勘查 (Ду Юйшэн, Сяо Хуайянь, Цянь Госян. Исследование внешнего города и водных путей Лояна династии Северная Вэй) // 考古 (Археология). - 1993. - № 7. - С. 602-608.

10. 傅喜年。中国古代建筑史 (Фу Синянь. История древней архитектуры Китая) : В 5 томах. - Т.2. - Пекин : Чжунго цзяньчжу гунъе, 2009. - 751 с.

11. 潘谷西。中国古代建筑史 (Пань Гуси. История древней архитектуры Китая) : В 5 томах. - Т.4. - Пекин : Чжунго цзяньчжу гунъе, 2009. - 643 с.

12. 王贵祥。中国汉传佛教建筑史 (Ван Гуйсян. История архитектуры чань-буддизма в Китае) : В 3 томах. - Пекин : издательство университета Цинхуа, 2016. - 2228 с.

13. Steinhardt. China's Earliest Mosques / Steinhardt, Nancy Shatzman // Journal of the Society of Architectural Historians. - 2008. - Vol. 67, no. 3. - P. 330-361.
14. Шевченко, М.Ю. Структура храма минтан в архитектуре Китая / М.Ю. Шевченко // Международный электронный сетевой научно-образовательный журнал "Architecture and Modern Information Technologies" - 2019. - № 1 (46) - C. 13-30.

15. Дмитриев, С.В. Древнекитайская градостроительная теория по данным Као гун цзи // Общество и государство в Китае: XXXIV научная конференция / С.В. Дмитриев Ин-т востоковедения; Сост. и отв. ред. Н.П. Свистунова. - М. : Восточная литература, 2004. - 304 с. - С. 74-91.

16. Кобзев А.И. Цзин тянь / А.И. Кобзев // Духовная культура Китая : энциклопедия : В 5 Т. Т. 1. Философия / ред. М.Л. Титаренко и др. - М. : Восточная литература, 2006. - 727 c. - С. 535-536.

17. Кобзев А.И., Дмитриев С.В. Као гун цзи / А.И. Кобзев, С.В. Дмитриев // Духовная культура Китая: энциклопедия : В 5 Т. Т. 5. Наука, техническая и военная мысль, здравоохранение и образование / ред. М.Л. Титаренко и др. - М. : Восточная литература, 2009. - 1055 с. - С. 706-713.

18. 日本建築史図集 (Иллюстрированная история японской архитектуры)/日本建築學會編集 (Гл. ред. Общество японской архитектуры). - Токио : SHOKOKUSHA, 2016. - 203 с.

19. 李文信。中国北部长城沿革考(上) (Ли Вэньсинь. Исследование развития Великой китайской стены на севере Китая (часть 1)) //社会科学辑刊 (Общественные науки). 1979. - № 1. - C. 128-141.

20. Lu Duanfang. Remaking Chinese urban form: Modernity, Scarcity and Space, 1949-2005. - London : Routledge, 2006. 204 p.

\section{References}

1. Liu Xujie. Zhongguo Gudai Jianzhushi [History of Ancient Chinese Architecture], vol. 1. Beijing, Zhongguo Jianzhu Gongye Publ., 2009, 717 p. (In Chinese)

2. Du Jinpeng. Xia Shang Zhou Kaoguxue Yanjiu [Archaeological Research of Xia, Shang and Zhou Dynasties]. Beijing, Kexue Publ., 789 p.

3. Zhouyuan Kaogudui [Zhouyuan Archaeological Team]. Shaanxi Fufeng Yuntang, Qizheng Xizhou Jianzhu Yizhi 19992000 Niandu Fajue Jianbao [Brief Report on Excavation of Buildings Foundations of The Western Zhou Dynasty in Qizhen County, Fufeng-Yuntang, Shaanxi Province, 1999-2000]. In: Kaogu [Archaeology], 2002, no. 9, pp. 3-26.

4. Shanxisheng Kaogu Yanjiusuo Houma Gongzuozhan [Shanxi Provincial Institute of Archaeology, Houma Workstation]. Shanxi Houma Jinguo Yizhi Niucun Gucheng de Shijue [Excavation of Niucun Ancient City at the Jin Kingdom Site in Houma, Shanxi]. In: Kaogu yu Wenwu [Archaeology and Cultural Relics], 1988, no. 1, pp. 57-60. (In Chinese)

5. Hebeisheng Wenwu Guanlichu [Hebei Provincial Cultural Relics Office] 河北省文物管理处 。河北省平山县战国时期 中山国墓葬发掘简报 [A Brief Report on The Excavation of The Zhongshan State Tombs of Warring States Period in Pingshan County, Hebei Province]. In: Wenwu [Cultural Relics], 1979, no. 1, pp. 1-31. (In Chinese) 
6. Zhongguo Kexueyuan Kaogu Yanjiusuo [Institute of Archaeology, Chinese Academy of Sciences]. Huixian Fajue Baogao [Huixian Excavation Report]. Beijing, Kexue Publ., 1956, 115 p. (In Chinese)

7. Yurkevich A.G. Zhou Li. In: Duhovnaja kul'tura Kitaja: jenciklopedija [Spiritual culture of China: an encyclopedia in five volumes], vol. 1 - Philosophy. Moscow, Vostochnajaliteratura Publ., 2006, 727 p p. 583. (In Russ.)

8. Xu Guangji, Gu Zhijie. Hebei Linzhang Ebeicheng Yizhi Chutan Fajue Jianbao [Brief Report on Exploration and Excavation of Northern Ye City Site in Linzhang, Hebei]. In: Kaogu [Archaeology], 1990, no. 7, pp. 595-600. (In Chinese)

9. Du Yusheng, Xiao Huaiyan, Qian Guoxiang. Beiwei Luoyang Waikuocheng he Shuidao de Kancha [Survey of Luoyang Outer City of the Northern Wei Dynasty and its Waterways]. In: Kaogu [Archaeology], 1993, no. 7, pp. 602-608. (In Chinese)

10. Fu Xinian. Zhongguo Gudai Jianzhushi [History of Ancient Chinese Architecture], vol. 2. Beijing, Zhongguo Jianzhu Gongye Publ., 2009, 751 p. (In Chinese)

11. Pan Guxi. Zhongguo Gudai Jianzhushi [History of Ancient Chinese Architecture], vol. 4. Beijing, Zhongguo Jianzhu Gongye Publ., 2009, 643 p. (In Chinese)

12. Wang Guixiang. Zhongguo Hanchuan Fojiao Jianzhushi [History of Chinese Buddhism Architecture]. Beijing: Tsinghua University Press, 2016. - 2228 p. (In Chinese)

13. Steinhardt, Nancy Shatzman. China's Earliest Mosques. In: Journal of the Society of Architectural Historians, vol. 67, no. 3 (September 2008), pp. 330-361.
14. Shevchenko M.Y. Struktura hrama mintan v arhitekture Kitaja [Structure of The Mingtang Temple in Chinese Architecture]. In: Architecture and Modern Information Technologies, 2019, no. 1(46), pp. 13-30. (In Russ.)

15. Dmitriev S.V. Drevnekitajskaja Gradostroitel'naja Teorija Po Dannym Kao Gong Ji [Ancient Chinese town planning theory according to Kao gong ji]. In: Obshhestvo i gosudarstvo v Kitae: XXXIV nauchnaja konferencija [Society and State in China] : 34th Scientific Conference. Moscow, Vostochnaja literatura Publ., 2004, 304 p., pp. 74-91. (In Russ.)

16. Kobzev A.I. Jin Tian. In: Duhovnaja kul'tura Kitaja: jenciklopedija [Spiritual culture of China: an encyclopedia in five volumes], vol. 1 - Philosophy. Moscow, Vostochnajaliteratura Publ., 2006, 727 p p. 535-536. (In Russ.)

17. Kobzev A.I., Dmitriev S.V. Kao Gong Ji. In: Duhovnaja kul'tura Kitaja: jenciklopedija [Spiritual culture of China: an encyclopedia in five volumes], vol. 5. Moscow, Vostochnaja literatura Publ., 2009, 1055 p pp. 706-713. (In Russ.)

18. Nihonkenchikushi zushū [An Illustrated History of Japanese Architecture]. Tokyo : SHOKOKUSHA Publ., 2016, 203 p. (In Japanese)

19. Li Wenxin. Zhongguo Beibu Changcheng Yange Kao [A Research on the Evolution of the Great Wall in Northern China], Part 1. In: Shehui Kexue Qikan [Social Science Journal], 1979, no. 1., pp. 128-141. (In Chinese)

20. Lu Duanfang. Remaking Chinese urban form: Modernity, scarcity and space, 1949-2005. London : Routledge, 2006. 204 p. 